\title{
Marandu, Xaraés and Piata Grasses Fertilized With Swine Wastewater Under Greenhouse Conditions
}

\author{
Marinho Rocho da Silva ${ }^{1}$, Joadil Gonçalves Abreu ${ }^{1}$, Oscarlina Lucia dos Santos Weber ${ }^{1}$, \\ Alexandra de Paiva Soares ${ }^{1}$, Edna Maria Bonfim-Silva ${ }^{2} \&$ Jefferson Vieira José $^{2}$ \\ ${ }^{1}$ Faculty of Agronomy and Animal Science, Federal University of Mato Grosso, Cuiabá, Brasil \\ ${ }^{2}$ Institute of Agrarian and Technological Sciences, Federal University of Mato Grosso, Rondonópolis, Brasil \\ Correspondence: Edna Maria Bonfim-Silva, Institute of Agrarian and Technological Sciences, Federal \\ University of Mato Grosso, Rondonópolis, MT, 5055 Students Avenue, 78.735-901, Brazil. Tel: \\ 55-669-8132-3814. E-mail: embonfim@hotmail.com
}

Received: March 25, 2019

Accepted: April 27, 2019 Online Published: June 30, 2019

doi:10.5539/jas.v11n9p112

URL: https://doi.org/10.5539/jas.v11n9p112

\begin{abstract}
The management of swine wastewater is of great importance where swine breeding is considerable and can represent an important fertilizer at maintenance of forages. The objective was to identify the Urochloa brizantha cultivar more responsive to fertilization with swine wastewater. The experimental design was in randomized blocks, with a $3 \times 5$ factorial scheme and four replications. The treatments consisted of three Urochloa brizantha cultivars (Marandu, Xaraés and Piatã) and five swine wastewater doses $\left(0.0 ; 3.5 ; 7.0 ; 10.5\right.$ and $14.0 \mathrm{~g} \mathrm{dm}^{3}$ pot $\left.^{-1}\right)$. The experiment was carried out in a greenhouse in the city of Cuiabá-MT. Three cuts were performed in the aerial part of the plants with intervals of 30 days between them. The application of the swine wastewater, regardless of the cultivar provided an increment in the production of dry mass, plant height, number of tillers, number of leaves and crude protein content, besides reducing the neutral detergent fiber and acid detergent fiber contents. The swine wastewater can be used as an alternative in the fertilization of Urochloa brizantha, because the cultivars were responsive to fertilization.
\end{abstract}

Keywords: alternative fertilizer, bio-fertilizer, forage, Protein, Urochloa brizantha

\section{Introduction}

Brazil is the world's fourth largest producer and exporter of swine (USDA, 2018). Swine breeding on country comes developing rapidly for as recent decades. The animals number increase results in higher production of swine wastewater, as well as the environmental impacts (Guimarães et al., 2017; Lopes et al., 2014; Yuan et al., 2018). This activity is considered potentially pollutant because it uses a lot of water in its production process, generating a large slurry volume (Sousa et al., 2014; Yuan et al., 2018)

The swine wastewater can represent an important fertilizer or potential environmental risk, depending on how the resource is managed (Boitt et al., 2018; Egewarth et al., 2015). Usually, after passing through the biodigester, it is stored in ponds or tanks to subsequently be applied in pastures or crops as fertilizer. Environmentally, requires specific treatments (Cabral et al., 2011; Guimarães et al., 2017), because there is risk of becoming a pollutant if its use does not respect soil adsorption capacity and the need for crops (Lourenzi et al., 2013; Orrico Junior et al., 2013).

However, fertilization using the swine wastewater when well-planned can bring benefits (Erthal et al., 2010; Matos et al., 2017), increasing macro and micronutrients availability in the soil (Angers et al., 2010; Matos et al., 2017; Tavanti et al., 2017), increasing water and nutrients adsorption by the plants (Galbiatti et al., 2011; Gomes et al., 2017) and the highest abundance in the soil fauna community (Silva et al., 2014). In the long term, the swine wastewater even increases the microbial activity and soil organic matter (Morales et al., 2015). The nitrogen, phosphorus and potassium are among the main nutrients that constitute the swine wastewater, limiting the forages production and maintenance. Therefore, its use can contribute to animal production to pasture, increasing the supply of forage in quantity and quality for animals (Boitt et al., 2018; Pandolfo \& Veiga, 2016; Serpa Filho et al., 2013). 
The forage grasses that adapt most to the soil and climate conditions in Brazil, are those of the genus Urochloa (Machado \& Assis, 2010). Among the species of this genus, 85\% belongs to Urochloa brizantha is considered one of the most productive. They are the most used as fodder source in the feeding of the bovine herd in Brazil. Among the species, Brachiaria brizantha cv. Marandu, Xaraés and Piatã. However, it demands study of the responses to fertilization with swine wastewater. In this sense, the objective was to identify the cultivar Urochloa brizantha more responsive to fertilization with swine wastewater.

\section{Method}

\subsection{Location and Experimental Design}

The experiment was carried out in a greenhouse located in the city of Cuiabá, MT, Brazil with geographic coordinates $15^{\circ} 36^{\prime} 31.31^{\prime \prime} \mathrm{S}, 56^{\circ} 3^{\prime} 49.44^{\prime \prime} \mathrm{W}$ in period of November 2013 to March 2014.

The experimental design was in randomized blocks, with a $3 \times 5$ factorial scheme, with four replications totaling 60 experimental plots. The treatments consisted of three cultivars of Urochloa brizantha (Marandu, Xaraés and Piatã) and five levels of swine wastewater $0.0 ; 3.5 ; 7.0 ; 10.5$ and $14.0 \mathrm{~g} \mathrm{dm}^{3}$ pot $^{-1}$, set to meet $0 ; 2550 ; 75$ and $100 \mathrm{mg} \mathrm{dm}^{-3}$ of nitrogen.

\subsection{Soil Characterization}

The experimental unit was defined by a pot with a capacity of $10 \mathrm{dm}^{3}$ of soil. The soil used was Oxisol (Soil Survey Staff, 2014). The physical-chemical characteristics in the depth from 0 to $20 \mathrm{~cm}$ (Parron et al., 2011) were the following: organic matter: $12.20 \% ; \mathrm{pH}$ in $\mathrm{CaCl}_{2}: 4.7 ; \mathrm{K}: 23 \mathrm{mg} \mathrm{dm}{ }^{-3} ; \mathrm{P}$ (Mehlich $\left.{ }^{-1}\right): 0.60 \mathrm{mg} \mathrm{dm}^{-3}$; Al: $0.30 \mathrm{cmol}_{\mathrm{c}} \mathrm{dm}^{-3} ; \mathrm{H}+\mathrm{Al}: 3.90 \mathrm{cmol}_{\mathrm{c}} \mathrm{dm}^{-3} ; \mathrm{Ca}^{2+}: 1.30 \mathrm{cmol}_{\mathrm{c}} \mathrm{dm}^{-3} ; \mathrm{Mg}^{2+}: 0.70 \mathrm{cmol}_{\mathrm{c}} \mathrm{dm}^{-3}$; Clay: $540 \mathrm{~g} \mathrm{~kg}^{-1}$; Silt: 91 $\mathrm{g} \mathrm{kg}^{-1}$; and Sand: $369 \mathrm{~g} \mathrm{~kg}^{-1}$.

\subsection{Swine Wastewater Characterization}

The swine wastewater used proceeded from the swine farming sector of the Federal Institute of Mato Grosso, São Vicente-MT Campus, from a stabilization pond. The chemical composition consisted of: compostable organic matter: $15.96 \%$; total carbon: $39.50 \%$; organic carbon: $9.26 \%$; $\mathrm{pH}$ in $\mathrm{CaCl}_{2}$ : 6.8 ; total nitrogen: $0.72 \%$; C/N ratio: 12:1; P: 5.14\%; K: 1.15\%; Ca: 3.97\%; Mg: 0.74\%; S: 0.19\%; Zn: $1165 \mathrm{mg} \mathrm{kg}^{-1}$; Cu: $382.36 \mathrm{mg} \mathrm{kg}^{-1}$; Mn: $994.3 \mathrm{mg} \mathrm{kg}^{-1}$; B: $145 \mathrm{mg} \mathrm{kg}^{-1}$; Fe: $2848.27 \mathrm{mg} \mathrm{kg}^{-1}$.

\subsection{Experiment Procedure}

The soil was sifted into 4mm mesh and applied limestone Filler (PRNT 99\%) to soil acidity correction. At 60 days after lime application, the seedlings transplanting was performed. To the complementary mineral fertilization of phosphorus $\left(90 \mathrm{mg} \mathrm{dm}{ }^{-3}\right.$ of $\left.\mathrm{P}_{2} \mathrm{O}_{5}\right)$ and potassium $\left(40 \mathrm{mg} \mathrm{dm}^{-3} \mathrm{~K}_{2} \mathrm{O}\right)$ was used as the source potassium phosphate. Liming and fertilization were performed according to (Guimarães et al., 1999).

The seeds of the cultivars were placed to germinate in tubes containing substrate. When they were approximately $20 \mathrm{~cm}$ high, two plants were transplanted to each pot. The doses of swine wastewater were applied in a single dose after establishment of forage plants in each plot (pot). Soil moisture was monitored through gravimetric, maintaining the soil with $70 \%$ of the field capacity.

After 30 days of transplanting the first cut of plants aerial part was performed $20 \mathrm{~cm}$ soil surface to standardize the height. At the time of the cut, the treatments were applied with the swine wastewater doses. The other plants aerial part cuts for evaluations also occurred $20 \mathrm{~cm}$ soil surface at 30,60 and 90 days after standardization.

\subsection{Sampling Procedures}

The plant material samples collected were weighed to obtain fresh mass, packing them into properly identified paper bags and taken to dry in a forced air circulation at the temperature of $55^{\circ} \mathrm{C}$ until constant weight.

Then the dry material was grinded into a Willey's mill and properly stored in plastics bags identified for bromatological composition determination hereafter. The nitrogen concentration was determined by the Kjeldahl method (Silva \& Queiroz, 2006).

\subsection{Analyzed Variables}

Averages of the three cuts per pot were made for the variables: plant height; number of leaves; number of tillers; crude protein content, neutral detergent fiber (NDF) and acid (ADF); production of forage per pot in the cuts for dry mass variable. For the determination of the fibrous fraction, the methods described by Van Soest (1994) were used, which divides the components of the sample into NDF and FDA. 


\subsection{Statistical Analyses}

The data were submitted to variance analysis with the results compared by regression analysis of the quantitative variables and by the Scott-Knott test $(\mathrm{P}>0.01)$ for qualitative variables.

\section{Results and Discussion}

\subsection{Plant Height, Number of Leaves, Number of Tillers, Dry Mass Production, Crude Protein Content}

The average data variance analysis of the variables plant height, number of leaves, number of tillers, dry mass production and crude protein content of the grasses, presented significance of factors isolated in the factor cultivars $(\mathrm{P}<0.05)$ and swine wastewater doses $(\mathrm{P}<0.01)$, the interaction between factors was not significant.

Among the three cultivars of Urochloa. brizantha, regardless of the levels of swine wastewater, there was a higher plant height in the Xaraés grass $(67.11 \mathrm{~cm})$, being $20.72 \%$ and $7.72 \%$ higher than Marandu and Piatã grasses, respectively. The dry mass production of Xaraés grass $\left(13.83 \mathrm{~g} \mathrm{pot}^{-1}\right)$, exceeded the production of Piatã grass in $17.90 \%$ and Marandu grass in $21.30 \%$.

The highest production of dry mass and height of Xaraés grass was also verified in a study carried out by (Euclides et al., 2008). The plant height of Xaraés grass is explained by the greater stem elongation. Productivity is due to its morphogenetic and structural characteristics (Lara \& Pedreira, 2011).

Table 1. Average plant height, number of leaves and tillers, dry mass production and crude protein content of three cultivars of $U$. brizantha

\begin{tabular}{lllll}
\hline Variables & Piatã & Marandu & Xaraés & CV (\%) \\
\hline Plant height $(\mathrm{cm})$ & $62.30 \mathrm{~b}$ & $55.59 \mathrm{c}$ & $67.11 \mathrm{a}$ & 5.83 \\
Number of leaves $\left(\mathrm{n}^{\mathrm{o}}\right.$ pot $\left.^{-1}\right)$ & $24.80 \mathrm{a}$ & $22.26 \mathrm{a}$ & $17.60 \mathrm{~b}$ & 19.23 \\
Number of tillers $\left(\mathrm{n}^{\mathrm{o}}\right.$ pot $\left.^{-1}\right)$ & $5.70 \mathrm{a}$ & $5.78 \mathrm{a}$ & $4.63 \mathrm{~b}$ & 20.99 \\
Dry mass production $\left(\mathrm{g} \mathrm{pot}^{-1}\right)$ & $11.73 \mathrm{~b}$ & $11.03 \mathrm{a}$ & $13.83 \mathrm{a}$ & 15.47 \\
Crude protein content $(\%)$ & $9.36 \mathrm{a}$ & $9.64 \mathrm{a}$ & $8.87 \mathrm{~b}$ & 9.14 \\
\hline
\end{tabular}

Note. Averages followed by the same letter in line does not differ from each other at a $1 \%$ probability level by the Scott-Knott grouping test.

The lowest number of leaves, tillers and crude protein content was in Xaraés grass. The lowest crude protein content $(8.87 \%)$ is explained by the higher height, less leaf production and greater stem elongation of this grass. In all cultivars, crude protein contents were above $8 \%$, considered the minimum percentage enough for adequate microbial activity of ruminants (Lazzarini et al., 2009).

Silva et al. (2015) reinforces the importance of the crude protein contents being increased because, if present in the forage offered to pasture, its reduction can be made via supplement and thus reduce the production costs, since this is a high-cost item in formulation of supplements for cattle.

In the factor swine wastewater doses the variables plant height, number of leaves, number of tillers and dry mass production of the grasses, presented a significant increasing linear polynomial model, with the exception of the crude protein content.

Results with increasing linear behavior were also found by Barnabé et al. (2007) with fertilization of 0;50;100 and $150 \mathrm{~m}^{3} \mathrm{ha}^{-1}$ of swine wastewater in Marandu grass and by Orrico Junior et al. (2012) who studied the effect of four doses of swine wastewater $\left(0 ; 100 ; 200\right.$ and $300 \mathrm{~kg} \mathrm{ha}^{-1}$ equivalent $\left.\mathrm{N}\right)$ on the dry mass production of Piatã grass.

The highest values of plant height, number of leaves and tillers were $70.54,33.36$ and 7.36 in the highest level of swine wastewater $\left(14 \mathrm{~g} \mathrm{dm}^{-3}\right)$, with an increment of $25 \%, 62.53 \%$ and $55.95 \%$, respectively, when compared to treatment without swine wastewater (Figure 1).

The nitrogen provided by the swine wastewater stimulated the forage plant growth, the tillering, the emergence of new leaves, and, consequently, the expansion of aerial part and root system (Galindo et al., 2018; Serafim \& Galbiatti, 2012), evidencing how much livestock production could be increased with the use of swine wastewater. Researches with forages plants confirmed that application of swine wastewater, promotes greater plant growth in relation to the control treatment (Brustolin-Golin et al., 2016; Galindo et al., 2018; Pandolfo \& Veiga, 2016). 
The increase in dry mass production $(76.12 \%)$ and crude protein content $(16.53 \%)$ occurred at the dose of $14 \mathrm{~d}$ $\mathrm{dm}^{-3}$ and $8.84 \mathrm{dm}^{-3}$ of pot respectively, which has as its main source nitrogen, which is important in regrowth of forage grasses. Galindo et al., (2018); Orrico Junior et al. (2013) observed an increase in crude protein content in Piatã grass under irrigation and application of swine wastewater, with values of $19.84 \%$ when the swine wastewater doses of $300 \mathrm{~m}^{3} \mathrm{ha}^{-1}$ were applied. Gomes et al. (2014) verified that the irrigation caused a positive influence on crude protein content with doses of swine wastewater applied in Piatã grass.
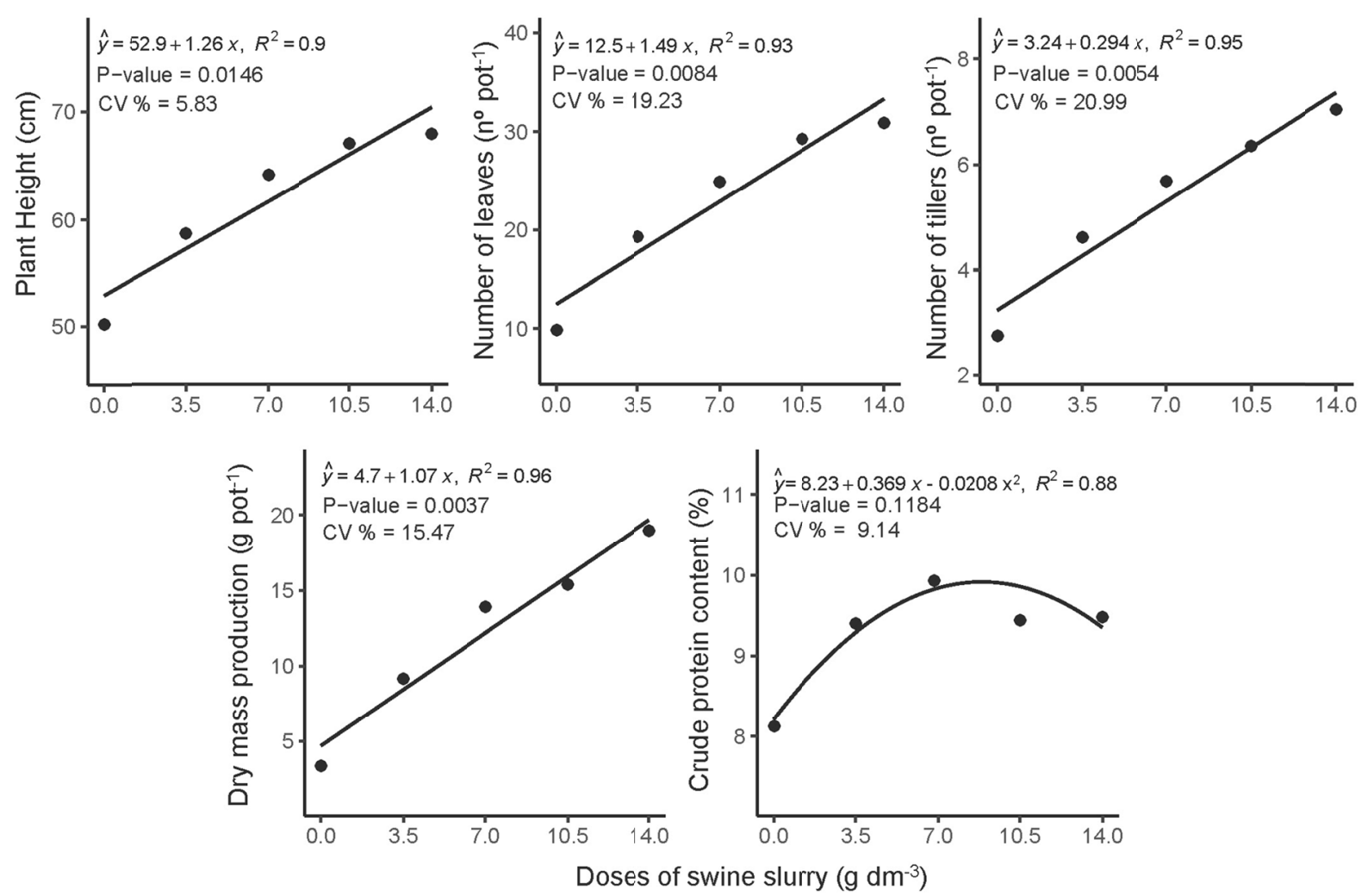

Figure 1. Plant height, number of leaves and tillers, dry mass production and crude protein content of cultivars of $U$. brizantha fertilized with swine wastewater

\subsection{Neutral Detergent Fiber (NDF) and Acid Detergent Fiber Contents}

In the results of variance analysis for the NDF and ADF contents, the factors cultivars and doses of swine wastewater, as well as the interaction between them $(\mathrm{P}<0.01)$, were significant.

A linear reduction in NDF and ADF levels was observed among the cultivars with the application of swine wastewater. There was a decrease of $0.36 ; 0.36$ and $0.31 \%$ in NDF for each unit increase in $\mathrm{g} \mathrm{dm}^{-3}$ of swine wastewater, for the Marandu, Piatã and Xaraés grasses, respectively (Figure 2).

Gomes et al. (2018) verified for Tifton 85 grass fertilized with swine wastewater, which with or without irrigation presence, the NDF and ADF contents decreased linearly.

In studies by Benett et al. (2008) and Orrico Junior et al. (2014), similar results were found applying swine wastewater in Piatã and Marandu grasses. According to the authors the reduction is due to the increasing linear effect of the swine wastewater levels on the number of leaves (Figure 1).

Johnson et al. (2001) worked with five nitrogen levels and three tropical grasses cultivars, observed that the NDF concentration decreases linearly with the increase in nitrogen fertilization.

Dry mass digestibility (NDF) ranged from 68.70 to 62.65 for the swine wastewater doses and cultivars, close to the one found by Melo et al. (2016) and Gomes et al. (2017) with Piatã grass, 66.8\% and 66\%, respectively.

The NDF content in forage is an important variable that defines its quality and limits the animal digestive capacity (Van Soest, 1994). According to the author, the improvement of the nutritive value of forages is linked 
to low levels of NDF (>65\%), which guarantees to ruminal microorganisms better utilization of nutrients in the diet and consequently better animal performance.
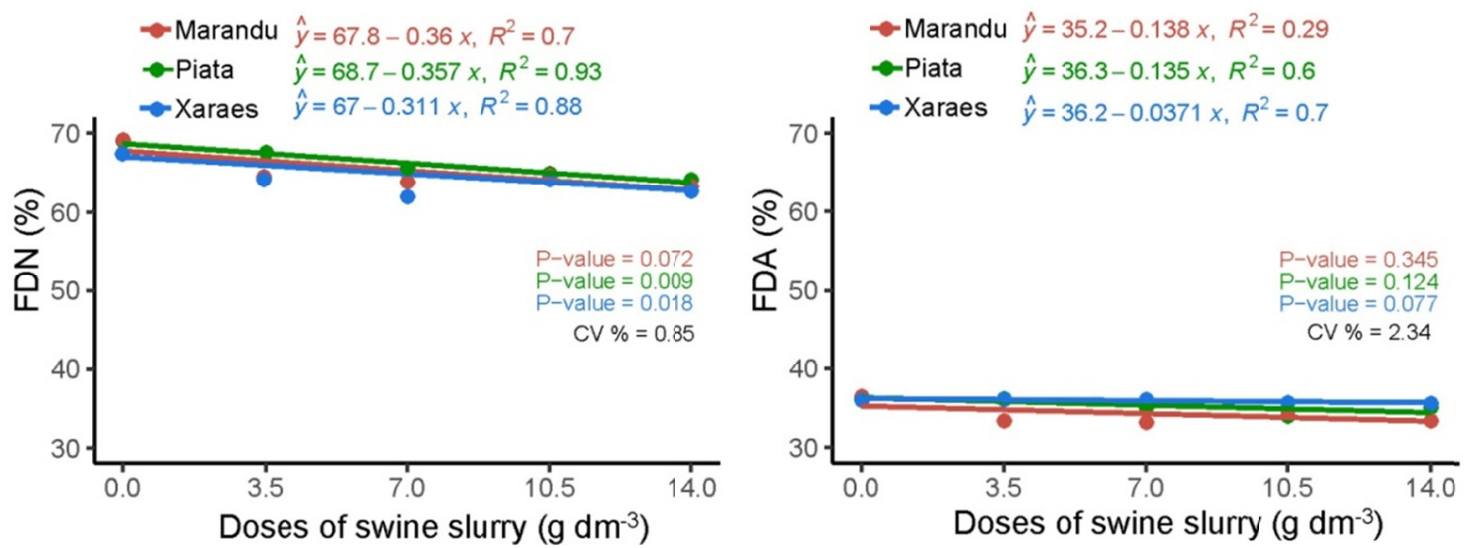

Figura 2. NDF and FDA contents of aerial part of $U$. brizantha cultivars under doses of liquid swine wastewater

The ADF contents ranged from 34.41 to $36.30 \%$; 33.31 to $35.25 \%$; for Piatã and Marandu grasses. The results were like those observed by (Orrico Junior et al., 2013) with variation of $31.96 \%$ to $36.76 \%$ in increasing doses of $\mathrm{N}\left(0 ; 100 ; 200\right.$ and $\left.300 \mathrm{~kg} \mathrm{ha}^{-1}\right)$ in Piatã grass. The results obtained are within the ideal range, according to (Nussio et al., 1998) that in works with forages recommended levels of about $30 \%$ of ADF, because levels above $40 \%$ can compromise the digestibility of forage.

Fertilization with swine wastewater can contribute to animal production to pasture, because it improved the productive and qualitative characteristics of the Marandu, Piatã and Xaraés grasses.

\section{Conclusions}

The swine wastewater can be used as an alternative in the fertilization of Urochloa brizantha providing positive responses with its application.

The swine wastewater increases production and improves the nutritive value of Marandu, Piatã and Xaraés grasses.

\section{References}

Angers, D. A., Chantigny, M. H., MacDonald, J. D., Rochette, P., \& Côté, D. (2010). Differential retention of carbon, nitrogen and phosphorus in grassland soil profiles with long-term manure application. Nutrient Cycling in Agroecosystems, 86, 225-229. https://doi.org/10.1007/s10705-009-9286-3

Barnabé, M. C., Rosa, B., Lopes, E., Rocha, G., Pinheiro, E., \& Freitas, K, (2007). Produção e composição químico- bromatológica da Brachiaria brizantha $\mathrm{CV}$. marandu adubada com dejetos líquidos de suínos. Ciência Animal Brasileira, 8, 435-446.

Benett, C. G. S., Buzetti, S., Silva, K. S., Bergamaschine, A. F., \& Fabricio, J. A. (2008). Produtividade e composição bromatológica do capim-marandu a fontes e doses de nitrogênio. Ciência Agrotecnológica, 32, 1629-1636. https://doi.org/10.1590/S1413-70542008000500041

Boitt, G., Schmitt, D. E., Gatiboni, L. C., Wakelin, S. A., Black, A., Sacomori, W., ... Condron, L. M. (2018). Fate of phosphorus applied to soil in pig slurry under cropping in southern Brazil. Geoderma, 321, 164-172. https://doi.org/10.1016/j.geoderma.2018.02.010

Brustolin-Golin, K. D., Scheffer-Basso, S. M., Escosteguy, P. A. V, Miranda, M., Travi, M. R. L., \& Zabot, V. (2016). Pig slurry in carpet grass pasture: Yield and plant-available nitrogen. Revista Brasileira de Engenharia Agrícola e Ambiental, 20, 795-799. https://doi.org/10.1590/1807-1929/agriambi.v20n9 p795-799

Cabral, J. R., Freitas, P. S. L. de, Rezende, R., Muniz, A. S., \& Bertonha, A. (2011). Impacto da água residuária de suinocultura no solo e na produção de capim-elefante. Revista Brasileira de Engenharia Agriíola e Ambiental, 15, 823-831. https://doi.org/10.1590/S1415-43662011000800009 
Egewarth, V. A., Egewarth, J. F., Prior, M., Sarto, M. V. M., Kaefer, K. A. C., Moratelli, G., ... Eckert, C. T. (2015). The effect of swine raising wastewater in the development of millet (Pennisetum glaucum L.), soil and leachate. African Journal of Agricultural Research, 10, 3206-3215. https://doi.org/10.5897/AJAR 2015.9872

Erthal, V. J. T., Ferreira, P. A., Matos, A. T. de, \& Pereira, O. G. (2010). Alterações físicas e químicas de um Argissolo pela aplicação de água residuária de bovinocultura. Revista Brasileira de Engenharia Agrícola e Ambiental, 14, 467-477. https://doi.org/10.1590/S1415-43662010000500003

Euclides, V. P. B., Macedo, M. C. M., Valle, C. B. do, Barbosa, R. A., \& Gonçalves, W. V. (2008). Produção de forragem e características da estrutura do dossel de cultivares de Brachiaria brizantha sob pastejo. Acta Scientiarum - Animal Sciences, 43, 1805-1812. https://doi.org/10.4025/actascianimsci.v32i2.8498

Galbiatti, J. A., Silva, F. G. da, Franco, C. F., \& Caramelo, A. D. (2011). Desenvolvimento do feijoeiro sob o uso de biofertilizante e adubação mineral. Engenharia Agrícola, 31, 167-177. https://doi.org/10.1590/ S0100-69162011000100017

Galindo, F. S., Buzetti, S., Teixeira Filho, M. C. M., Dupas, E., \& Carvalho, F. da C. (2018). Nitrogen management in mombasa guineagrass as a function of sources and rates of nitrogen. Revista de Ciências Agrárias, 41, 31-40. https://doi.org/10.19084/rca18131

Gomes, E. P., Sanches, A. C., Deboleto, J. G. G., de Jesus, F. L. F., \& Mendonça, F. C. (2017). Productivity and nutritional quality of Urochloa brizantha cv. BRS Piatã grass fertirrigated with swine wastewater in different seasons of the year. Australian Journal of Crop Science, 11, 1366-1373. https://doi.org/10.21475/ ajcs.17.11.10.pne732

Gomes, E. P., Sanches, A. C., Dias, D. kenedys U., Jesus, F. L. F. de, Nunes, W. A. G. de A., ... Azevedo, E. P. G. (2018). Application of swine wastewater for irrigation of Tifton 85 grass: Part I-productivity and nutritional quality. Australian Journal of Crop Science, 12, 486-495. https://doi.org/10.21475/ajcs.18.12. 03.pne985

Gomes, E. P., Silva, L. F., Deboleto, J. G. G., \& Dias, D. K. U. (2014). Produtividade e qualidade do capim Piatã sob doses de dejeto suíno líquido tratado na presença e ausência de irrigação. Cadernos de Agroecologia, 4, $1-10$.

Guimarães, D., Amaral, G., Maia, G., Lemos, M., \& Custodio, S. (2017). Suinocultura: Estrutura da cadeia produtiva , panorama do setor no Brasil e no mundo e o apoio do Bndes. Agroindústria, 45, 85-136.

Guimarães, P. T. G., Alvarez, V. H., \& Ribeiro, A. C. (1999). Recomendações Para o Uso de Corretivos e Fertilizantes em Minas Gerais (5th ed.). Comissão de Fertilidade do Solo do Estado de Minas Gerais. Viçosa.

Johnson, C. R., Reiling, B. A., Mislevy, P., \& Hall, M. B. (2001). Effects of nitrogen fertilization and harvest date on yield, digestibility, fiber, and protein fractions of tropical grasses. Journal of Animal Science, 79, 2439. https://doi.org/10.2527/2001.7992439x

Lara, M. A. S., \& Pedreira, C. G. S. (2011). Structural and morphogenetic responses of swards of Brachiaria species to defoliation intensity. Pesquisa Agropecuaria Brasileira, 46, 760-767. https://doi.org/10.1590/ S0100-204X2011000700012

Lazzarini, I., Detmann, E., Sampaio, C. B., Paulino, M. F., Filho, S. de C.V., Souza, M. A. de, \& Oliveira, F. A. (2009). Dinâmica ruminal da fibra em detergente neutro em bovinos alimentados com forragem tropical de baixa qualidade e suplemento com compostos nitrogenados. Revista Brasileira de Zootecnia, 61, 635-647.

Lopes, A. D. S., Hernandez, F. B. T., Alves Júnior, J., \& liveira, G. Q. (2014). Distribution of the root system of peach palm under drip irrigation. Acta Scientiarum. Agronomy, 36, 317. https://doi.org/10.4025/ actasciagron.v36i3.16281

Lourenzi, C. R., Ceretta, C. A., Silva, L. S. da, Girotto, E., Lorensini, F., Tiecher, T. L., De Conti, L., Trentin, G., Brunetto, G. (2013). Nutrients in soil layers under no-tillage after successive pig slurry applications. Revista Brasileira de Ciência do Solo, 37, 157-167. https://doi.org/10.1590/S0100-06832013000100016

Machado, L. A. Z., \& Assis, P. G. G. de, (2010). Produção de palha e forragem por espécies anuais e perenes em sucessão à soja. Pesquisa Agropecuaria Brasileira, 45, 415-422. https://doi.org/10.1590/S0100-204X 2010000400010 
Matos, M. A. de, Barbosa, G. M. de C., Nogueira, M. A., Colozzi, F. A., Andrade, D. S., \& Caviglione, J. H. (2017). Chemical and microbiological changes in a sandy soil with pig liquid waste application in Southern Brazil. African Journal of Agricultural Research, 11, 5000-5007. https://doi.org/10.5897/ajar2016.11777

Morales, D., Vargas, M. M., Oliveira, M. P. de, Taffe, B. L., Comin, J., Soares, C. R., \& Lovato, P. (2015). Response of soil microbiota to nine-year application of swine manure and urea. Ciência Rural, 46, $260-266$. https://doi.org/10.1590/0103-8478cr20140565

Nussio, L. G., Manzano, R. P., Pedreira, C. G. S. (1998). Valor alimentício em plantas do gênero Cynodon. Simpósio Sobre Manejo da Pastagem (pp. 203-242). Piracicaba.

Orrico Junior, M. A. P., Centurion, S. R., Amorim Orrico, A. C., \& da Silva S. N. (2012). Effects of biofertilizer rates on the structural, morphogenetic and productive characteristics of Piatã grass. Revista Brasileira de Zootecnia, 41, 1378-1384. https://doi.org/10.1590/S1516-35982012000600009

Orrico Junior, M. A. P., Orrico, A. C. A., Centurion, S. R., \& Sunada, N. da S. (2014). Potencial bromatológico do capim Piatã cultivado em sistema orgânico. Revista Agrarian, 7, 447-453.

Orrico Junior, M. A. P., Orrico, A. C. A., Centurion, S. R., Sunada, N. da S., \& Junior, J. de L. (2013). Valor nutritivo do capim Piatã adubado com diferentes doses de biofertilizante. Revista Agrarian, 6, 312-319.

Pandolfo, C. M., \& Veiga, M. da, (2016). Crop yield and nutrient balance influenced by shoot biomass management and pig slurry application. Revista Brasileira de Engenharia Agrícola e Ambiental, 20, 302-307. https://doi.org/10.1590/1807-1929/agriambi.v20n4p302-307

Parron, L. M., Muniz, D. H. de F., \& Pereira, C. M. (2011). Manual de Procedimentos de Amostragem e Análise Físico-Química de Água. Embrapa Florestas-Documentos 232. https://doi.org/10.13140/RG.2.1.2110.9608

Santos, H. G. dos, Jacomine, P. K. T., Anjos, L. H. C. dos, Oliveira, V. Á. de, Oliveira, J. B. de, Coelho, M. R., ... Cunha, T. J. F. (2018). Sistema brasileiro de classificação de solos. Rio de Janeiro: Embrapa Solos. https://doi.org/ISBN 978-85-7035-198-2

Serafim, R. S., \& Galbiatti, J. A. (2012). Efeito da aplicaçao de água residuária de suinocultura na Brachiaria Brizantha cv Marandu. Revista Colombiana de Ciencia Animal, 4, 185-203. https://doi.org/10.24188/ recia.v4.n1.2012.307

Serpa Filho, R., Sehnem, S., Cericato, A., Santos Junior, S., \&Fischer, A., (2013). Compostagem de dejetos de suínos. Revista em Agronegócios e Meio Ambiente, 6, 47-78.

Silva, A. de A., Lana, Â. M. Q., Lana, R. M. Q., \& Costa, A. M. da, (2015). Fertilização com dejetos suínos: influência nas características bromatológicas da Brachiaria decumbens e alterações no solo. Engenharia Agrícola, 35, 254-265. https://doi.org/10.1590/1809-4430-Eng.Agric.v35n2p254-265/2015

Silva, D., Queiroz, A.C. de, (2006). Análise dos alimentos (Métodos químicos e biológicos) (3rd ed.). MG: Universidade Federal de Viçosa, Viçosa.

Silva, R. F. da, Bertollo, G. M., Corassa, G. M., Cocco, L. B., Steffen, R. B., \& Basso, C. J. (2014). Doses de dejeto líquido de suínos na comunidade da fauna edáfica em sistema plantio direto e cultivo mínimo. Ciência Rural, 44, 418-424. https://doi.org/10.1590/s0103-84782014000300006

Soil Survey Staff. (2014). Soil Survey Field and Laboratory Methods Manual. USDA-NRCS Web Soil Survey WebSoil Survey Investigations. https://doi.org/10.13140/RG.2.1.3803.8889

Sousa, F. A., Campos, A. T., Silva, E. de B., Gandini, A. M. M., \& Corrêa, J. M. (2014). Redução do potencial poluidor de dejetos de suínos em lagoas de estabilização em série. Bioscience Journal, 30, 65-73.

Tavanti, R. F. R., Silva, F., O., Tavanti, T. R., Lorenzon, K., Santos, M. I., Demicheli, M., ... Breda, C. C. (2017). Crop productivity and soil quality after fertilization with liquid swine manure. Acta Agronomica, 67. https://doi.org/10.15446/acag.v67n2.65684

USDA. (2018). World Agricultural Supply and Demand Estimates. USDA, USA.

Van Soest, P. (1994). Nutritional ecology of the ruminant. Cornell University Press, Ithaca and London.

Yuan, Z., Pan, X., Chen, T., Liu, X., Zhang, Y., Jiang, S., Sheng, H., \& Zhang, L. (2018). Evaluating environmental impacts of pig slurry treatment technologies with a life-cycle perspective. Journal of Cleaner Production, 188, 840-850. https://doi.org/10.1016/j.jclepro.2018.04.021 


\section{Copyrights}

Copyright for this article is retained by the author(s), with first publication rights granted to the journal.

This is an open-access article distributed under the terms and conditions of the Creative Commons Attribution license (http://creativecommons.org/licenses/by/4.0/). 